\title{
Barriers in teacher perception about the use of technology for evaluation in Higher Education
}

\author{
Rosita Romero Alonso \\ reromero@inacap.cl \\ Universidad Tecnológica de Chile INACAP, Chile \\ Irma Riquelme Plaza \\ irma.riquelme@inacapmail.cl \\ Universidad Tecnológica de Chile INACAP, Chile \\ Carol Halal Orfali \\ carol.halal@inacapmail.cl \\ Universidad Tecnológica de Chile INACAP, Chile
}

\begin{abstract}
This article describes barriers in higher education teachers' perceptions facing changes when innovating in their evaluation practices by integrating information and communication technologies (ICT) in a Chilean university. Forming and evaluating in a competency-based approach involves challenges for the teaching staff and changes in their role that are accepted or resisted. The same happens in the face of innovation processes with information and communication technologies (ICT) integration in teaching practices.

The primary results show a relationship between pedagogical beliefs and evaluation which is consistent with adoption and assessment of the digital tool used. In addition, it reveals the role of beliefs as secondary barriers to change in the face of teaching practices with the use of technology (Ertmer, Ottenbreit-Leftwich, Sadik, Sendurur, \& Sendurur, 2012). This study identifies the value of autonomy in student work and feedback as key beliefs in technology adoption.
\end{abstract}

\section{Keywords}

Barriers, ICT; professional competences; higher education; evaluation of competences; evaluation tools 


\section{Introduction}

In the Chilean educational system, it is necessary to ensure quality training to update teacher knowledge and provide students with diverse academic spaces relevant to the fields of knowledge of the taught courses (OECD, 2005). One aspect to ensure the relevance of training with the professional context of graduates is the implementation of training systems based on competencies (Tejada Fernández, 2012; Valle \& Manso, 2013).

Effectively implementing such training involves a paradigm shift in the method of approaching evaluation and the role of the teaching staff as evaluators (Cano \& Ion, 2012; Tejada Fernández \& Ruiz Bueno, 2016). Therefore, reviewing formative coherence and the identification of learning tasks or evidence that can account for the training and development of competences is a challenge both in managing plans of study as well as organising and working on teaching teams (Cano, 2015a; Romero \& Halal, 2013).

On the other hand, social and communication changes have developed the need to integrate new technologies in the higher education training processes (García-Varcárcel, 2011). The use of technologies has been introduced in the teaching-learning process, which involves evaluation (Cano, 2015a; Cano \& Ion, 2012). Moreover, these initiatives involve changes in the practices of teachers and training centres regarding their implementation (Fainholc, Nervi, Romero, \& Halal, 2015; Sancho-Gil, Alonso Cano, \& Sánchez-Valero, 2018).

This article describes the findings from a study held with higher education Chilean teachers and their barriers in perceptions when innovating in their evaluation practices by integrating information and communication technologies (ICT) in a Chilean university.

\section{a. Evaluation of competencies in Higher Education}

From classrooms, we observe how society becomes more and more specialised; information is accessible and constantly changing. This last point strongly affects training processes, the traditional educational paradigm based on transmission is relegated (Hargreaves, 2003). Training institutions seek strategies to integrate this reality and incorporate elements that strengthen professional training in the face of changing scenarios (Cano \& Ion, 2012). Teachers and teaching practices are challenged to propose learning situations that bring students closer to the professional reality.

A training perspective in higher education that seeks to account for this need is the competencybased training approach, promoted by the OECD at the European Higher Education Area in Bologna 1999. South America, and specifically Chile, develops similar proposals to organise higher education (Beneitone et al., 2007). With this approach, competent students develop not only conceptual practice but also skills and attitudes, which allow them to act efficiently in complex situations in a specific context (Le Boterf, 2011; Perrenaud, 2004). These competences are in constant development and progress throughout their entire lives, including their job performance (Cano, 2015a).

Accepting the new approach includes changes in the entire teaching-learning process, which also involves the roles of teachers and students. Teachers need to adapt their planning, management of classroom activities, integrate the pedagogical use of ICT and adapt the evaluation process and their way of relating to students (Espinosa, 2014; Zabalza Beraza, 2009). Whereas students are expected to develop reflection skills, the ability to work collaboratively, act autonomously and consider evaluation as one more element of the process that drives learning through feedback processes (Cebrian de la Serna, Serrano Angulo, \& Ruiz Torres, 2014; Gil Flores \& Padilla Carmona, 2013).

From the perspective of competences, evaluation entails a change in the role of the teacher, who becomes an observer of the student's performance. Strategies such as evaluation portfolios, 
learning folders, project-based learning, case analysis and simulations allow learning to be developed considering the context and its complexity (Margalef García, 2014; Medina Moya, Jarauta Borrasca, \& Urquiza Sánchez, 2005; Tejada Fernández \& Ruiz Bueno, 2016). Contrarily, institutions should support this change by intending to observe performance in evaluations (Cano \& Ion, 2012; Gil Flores \& Padilla Carmona, 2013; Margalef García, 2014; Mateo \& Vlachopoulos, 2013).

To observe performance, evaluation instruments such as checklists, rating scales and rubrics are used. The rubric is among the most used instruments in this area and helps students to check their progress, gain knowledge about what is expected, reduce anxiety and improve self-regulation, especially from the structure and detail of the feedback which guides and characterises the performance observed (Cano, 2015a; Panadero \& Jonsson, 2013). Feedback supports continuous and self-regulated learning by students, who can be an active part of the evaluation (Boud \& Molloy, 2015).

\section{b. Teaching practices and ICT in the teaching-learning process.}

As new context is driving training by competency, it is also generating new challenges in technology integration in training processes. Again, this integration, in addition to involving changes in pedagogical relationships, means that teachers and students are called to new roles to which they adapt or resist. Both represent advantages to this integration that requires didactic planning (García-Varcárcel, 2011).

Although ICT use in higher education is a reality, there is still a lack of true integration in the teaching-learning process due to poor teacher training, among other things (Camacho, 2014). Among the technologies used to support face-to-face teaching are virtual spaces or Learning Management System (LMS) platforms, which can be defined as software that provides a space for teaching organisation. With the tools available, it simplifies various tasks, including evaluation, enabling the development of online tests and evaluation guidelines in the rubric module, which supports the implementation of various teaching and evaluation strategies. In many cases, this integration is formal and limited to using the virtual space as a repository of content (PérezBerenguer \& García-Molina, 2016). When considering its use for evaluation and in addition to faceto-face teaching, such as using the web along with 'web-supplemented' classroom, the modality of integrating this technology has been conceived at a primary level (OECD, 2005). To varying degrees, these platforms have been a strategy for enriching the educational practice and space for teacher reflection (Fainholc et al., 2015).

Several authors warn that integrating any technology should maintain the precaution of always being in accordance with educational goals and not putting tools before educational needs (Area Moreina, Hernández Rivero, \& Sosa Alonso, 2016; Bosco, Sánchez-Valero, \& Sancho-Gil, 2016). Similarly, the experience of successfully implementing this integration is strongly related to the careful selection of tools based on previously defined needs (Area, Sanabria \& González, 2008). Faced with this, the need to understand this integration openly and flexibly emerges because each training process will require various educational actions and different technological support tools for its implementation (Bartolomé Piña, 2008). On the other hand, developing educational policies that support adoption looking at the complexity of the phenomenon has also been considered a necessity (Area Moreina et al., 2016; Area Moreira, 2006; Área Moreira, San Nicolás Santos, \& Fariña Vargas, 2010; Forés, Sánchez, \& Sancho-Gil, 2014; Romero \& Sancho, 2013).

\section{c. Teacher perceptions on adopting pedagogical practices with ICT}

There is ample production of studies regarding the role of beliefs on adopting technologies in education. Beliefs can be understood as subjective constructions that are considered true by an individual or group. Since the end of the 1990s, perceptions have been demonstrated about the 
external elements associated with accessing technologies for education (primary barriers), which were an important aspect for the teaching staff when innovating using technology, but that along with these, the beliefs on use were established (secondary barriers) and had the strength to become an obstacle to ICT adoption (Ertmer, 1999; Pelgrum, 2001). Throughout the following years, this view has been reaffirmed, confirming that technology use does not ensure the transformation of pedagogical practices because the practice is a reflection of the teachers' beliefs (Area Moreira, 2006; Coll Salvador, C.; Rochera Villach, M. J.; Mayordomo Saiz, R. M.; Naranjo Llanos, 2008; Pablos Pons, Colás Bravo, \& Villaciervos Moreno, 2010; Tondeur, Hermans, van Braak, \& Valcke, 2008). Over time, greater possibilities of accessing technology have displaced the primary barriers and positioned the role of beliefs after the processes of adopting technology for pedagogical use (Admiraal et al., 2017; Arancibia, Halal, \& Romero, 2017; Ertmer et al., 2012; Kim, Kim, Lee, Spector, \& DeMeester, 2013; Liu, 2011).

Determining the type of beliefs that favour adopting technology in teaching practices has provided evidence that adherence to a constructivist paradigm seems to be relevant, although not exclusive (Ertmer et al., 2012). The importance of context as a barrier (Salinas, Nussbaum, Herrera, Solarte, \& Aldunate, 2017) and the value of the institution's culture of accepting change are shown to have a strong incidence of adopting technology (Reid, 2014). In addition, teacher typologies generate recommendations for the conduct of technological innovation processes, distinguishing diversity of views and predispositions to ICT use (Admiraal et al., 2017).

From this perspective, technology adoption and intention of use by teachers in higher education considers four variables: expectations of the results (the strongest predictor), expectation of effort (the weakest predictor), social influence and facilitator conditions. Studies indicate that there is a greater predisposition to use technology in infrastructures and a social influence that supports its adoption (Martín García, García del Dujo, \& Muñoz Rodríguez, 2014; Padilla, Moreno, \& Hernández, 2016; Reyes González \& Martín García, 2016).

In the enrichment of pedagogical practices with ICT use, the educational institution's coordination is relevant (Hargreaves \& Fink, 2004). They must consider teaching knowledge, assessing and accompanying it in the development of skills and abilities so that the change takes place. Universities remain under a conservative paradigm, which is why it is important to support teachers in their training considering their typology and specific barriers, as well as working on their skills, their beliefs and articulate pedagogy and technology (Admiraal et al., 2017; Dominguez Díaz, 2016; Reyes González \& Martín García, 2016; Tapasco \& Giraldo, 2017). The causes that motivate this change must be a fundamental part of the debate and reflection in order to progress in innovation development and improvement processes (Manso, Pérez, Libedinsky, Light, \& Garzón, 2011).

Therefore, by recognising the complexity of the challenge of integrating technology in academic training processes, in 2014, 2015 and 2016, our team participated in the development of a pedagogical innovation project that integrated the Moodle platform for online evaluation. Based on this experience, we believe it is important to know the aspects that influence the adoption of this change of practices with technology use by teachers. In this article, we address the findings with regard to the behaviour of primary and secondary barriers (Ertmer et al., 2012) present in the discourse of the teachers who participated in the project.

\section{Methodology}

\section{a. Design and strategies for data collection}

This qualitative research study corresponds to a case study as a research strategy because it aims to deeply understand a reality through description and analysis of meaning from the subjects 
involved, while highlighting the subjective character of its construction as the theoretical element that forms the basis of this case in particular (Stake, 2007).

Understanding that the phenomena associated with educational change and the integration of technology respond to personal and collective imaginations, wherein a series of factors promote change and innovation converges (Admiraal et al., 2017; Ertmer et al., 2012), we decided to access the information through conversational and narrative data collection techniques: interview and discussion groups. The focused interview, in terms of Flick (2007), allowed us to deepen teacher perceptions regarding the integration of the Moodle platform for online evaluation used in the project in 2014 and 2015. At the same time, the discussion groups only covered the participating teachers in 2016, which almost doubled in number. With the interviews, we had a detailed personal view of the experience and in the discussion groups, we tried to compare views and confirm perceptions (Suárez, 2005), which emerged in the interviews conducted in previous years. Both applied techniques allowed us to focus on the context of the data to be collected (Flick, 2015).

\section{b. Key reporting}

This study is based on the implementation of a project on the use of Moodle for online learning evaluation, specifically of key performances in participating degrees. This institution has instituted in its curriculum the integration of courses that act as evaluative milestones that enable inferring progress of competences developed in the graduate profile of their careers (Tardif, 2008). To make national comparisons and observe the behaviour of the evaluation indicators and the progress of the competences, we proposed teachers of these subjects use common observation tools (rubrics) and respond to them online to have a general look at the training progress.

The reporting teachers, 35 in total, participated in the implementation of this project, which in its pilot stage was applied successively in 2014, 2015 and 2016. Eight (8) teachers were part of the project in 2014, ten (10) in 2015 and seventeen (17) in 2016. Twenty (20) of them were interviewed and the other fifteen (15) participated in three discussion groups. The decision of including discussion groups in the last year was due to the concentration of teachers in some campuses. See details in Table 1.

The selection of teachers was based on criteria that protected heterogeneity (gender, discipline, campus) to investigate a variety of discourses or perspectives (Álvarez-Gayou, 2003). Representatives from the three knowledge areas that wanted to participate are in the project (automotive mechanics, construction and telecommunications) as well as belong to four campuses from different geographical areas of the country (fifth, ninth and tenth regions and the metropolitan region of Santiago). These two criteria sought to represent local situations and aspects of the different disciplinary areas that could be affecting the adoption of the suggested evaluation practice.

\begin{tabular}{llllllll}
\hline & $\mathbf{2 0 1 4}$ & & $\mathbf{2 0 1 5}$ & & $\mathbf{2 0 1 6}$ & Total \\
\hline & Men & Women & Men & Women & Men & Women \\
\hline Sth Region & 3 & 0 & 0 & 0 & 1 & 1 & 5 \\
\hline 9th Region & 2 & 1 & 2 & 2 & 4 & 1 & 12 \\
\hline $\begin{array}{l}\text { 10th Region } \\
\text { Metropolitan }\end{array}$ & 0 & 0 & 2 & 0 & 3 & 0 & 5 \\
\hline \begin{tabular}{l} 
Region \\
\hline
\end{tabular} & 1 & 1 & 3 & 1 & 5 & 2 & 13 \\
\hline
\end{tabular}




\begin{tabular}{llllllll}
\hline Annual Total & 6 & 2 & 7 & 3 & 13 & 4 & 35 \\
\hline
\end{tabular}

Table 1. Teachers participating in interviews and discussion groups

Source: Created by the authors

\section{c. Data analysis}

As a general method, qualitative content analysis is applied (Flick, 2007) with the purpose of reducing, organising and giving an explanatory meaning to the data collected (Álvarez-Gayou, 2003; Schreier, 2014). This process is supported with the qualitative analysis software AtlasTi.

In the first instance, an open coding was carried out (Flick, 2007) that identified 32 initial codes in the set of texts analysed. After a second reading of the data, these codes were refined (Saldaña, 2013) and limited to 22 (see Table 2), which included aspects such as teachers' beliefs regarding ways of learning, evaluation and students, their evaluations regarding the usefulness of the online evaluation platform, aspects of training and access to resources needed for appropriate ICT use and administrative support needs. Each of the texts was coded by two researchers.

\begin{tabular}{|c|c|}
\hline Family of Codes & Codes \\
\hline \multirow[t]{4}{*}{ Primary barriers } & 1. Training (for ICT use) \\
\hline & 2. Internet connection \\
\hline & 3. Technological resources \\
\hline & 4. Platform operation \\
\hline \multirow[t]{3}{*}{ Beliefs } & 5. Beliefs about learning \\
\hline & 6. Beliefs about evaluation \\
\hline & 7. Beliefs about students \\
\hline \multirow{3}{*}{$\begin{array}{l}\text { Evaluation } \quad b y \\
\text { competences } \\
\text { approach }\end{array}$} & 8. Feedback to students \\
\hline & 9. Student-centred learning \\
\hline & 10. Student autonomy \\
\hline \multirow{3}{*}{$\begin{array}{l}\text { Digital evaluation } \\
\text { value }\end{array}$} & 11. Platform acceptance \\
\hline & 12. Advantages of using the platform \\
\hline & 13. Disadvantages of using the platform \\
\hline \multirow[t]{3}{*}{ Platform uses } & 14. Usability (stated uses) \\
\hline & 15. Adapting technology to their practices \\
\hline & 16. Difficulties of adoption \\
\hline \multirow[t]{3}{*}{ Pilot implementation } & 17. External support \\
\hline & 18. Implementation flaws \\
\hline & 19. Training to use the platform \\
\hline \multirow[t]{3}{*}{ Context } & 20. Area \\
\hline & 21. Campus (geographical location) \\
\hline & 22. Time and priorities \\
\hline
\end{tabular}

Table 2. Codes and their grouping by families

Source: Created by the authors 
By analysing the behaviour of the codes in the set of texts, the configuration of categories was reviewed. This procedure was carried out using thematic grouping. Relationships were first established from a matrix that grouped the categories and their behaviour was observed in the interviews that accounted for individual processes, which was later confirmed in the discussion groups as trends. The internal relationship between the key codes of the 20 interviews allowed us to form regular cases (see Graph 1). The behaviour of the relationships between codes collected both in the interviews and the discussion groups was graphed with the AtlasTi programme, allowing us to represent these senses in relationship networks (Saldaña, 2013; Schreier, 2014). A new group re-reading of the coded pieces allowed us to identify extracts from the conversation that were representative of the relevant relationships observed. To conclude, the set of situations were represented in a graph, which sought an interpretation that reconstructed the set of relationships and cases globally through theorising (Staller, 2015).

In this way, beliefs and barriers emerged affecting the adoption of this new assessment practice with the use of ICT in the sample group of teachers.

\section{Results}

Using the overall results, we observed that, of the 20 teachers interviewed, twelve (12) of them indicate having beliefs about learning and/or evaluation centred on the student, and correspondingly, they have a positive appreciation of using the online evaluation platform as an advantage in their pedagogical practices. In opposition, another five (5) teachers state a learning and/or evaluation position centred on the teacher while they find disadvantages of using the tool. In the other three (3) cases, it is not possible to find this relationship due to the lack of comments regarding beliefs (one case), the difficulty of adhering to an evaluation position due to not understanding the concepts (one case) and the difficulty of adapting teaching practices, centred on the student, to the use of the tool, which leads the teacher to reject it (one case). Figure 1 positions these cases in the axes based on the assessment of technology use and the concept of learning and evaluation, specifically, on the value of feedback and student-centred learning. 


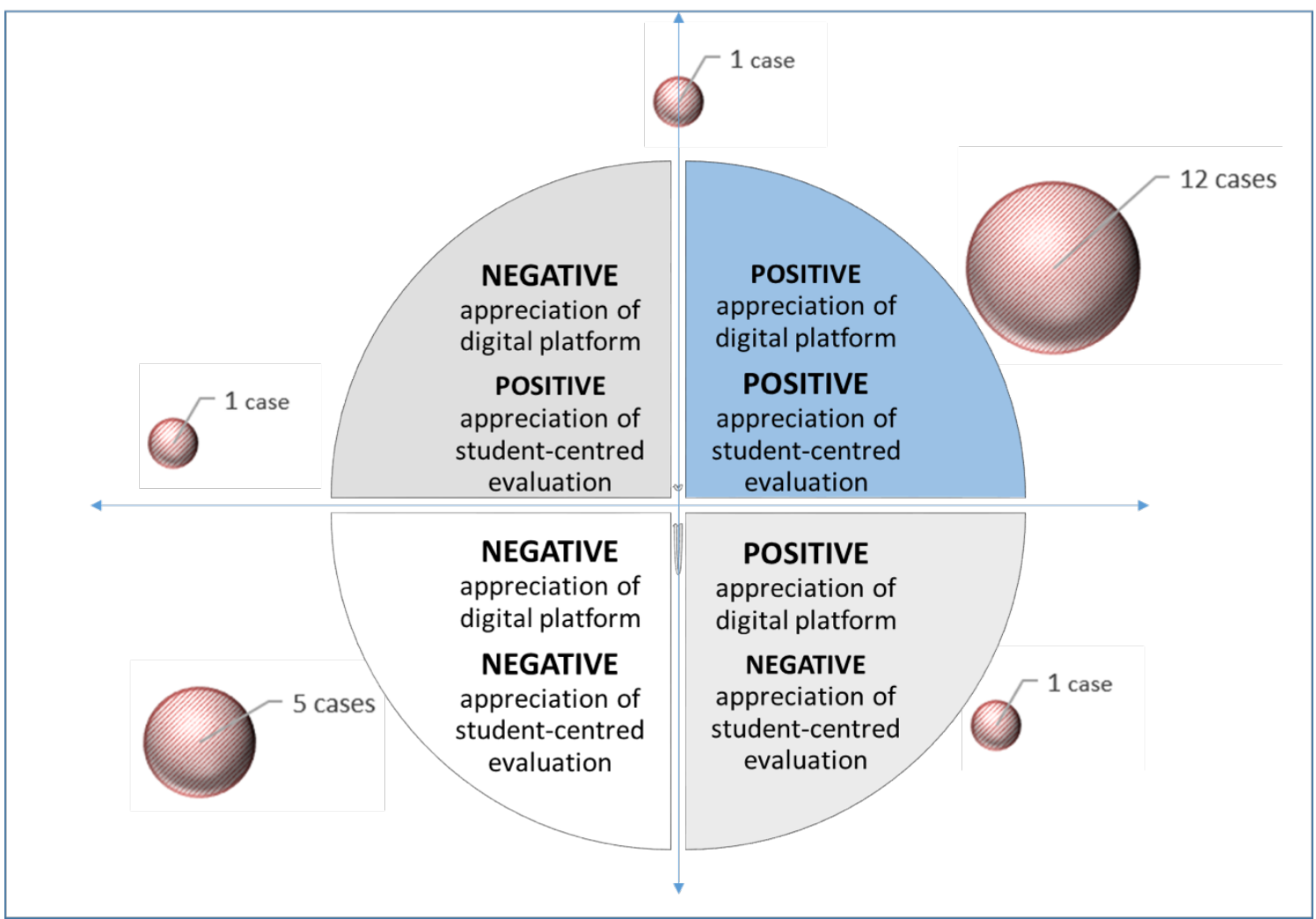

Figure 1. Relationship between beliefs and assessment of ICT use in evaluation. 20 cases.

Source: Created by the authors

Although the relationships represented in Figure 1 seem logical to us (facing the change in practices that was sought in this project), it is interesting to note it in the 17 effective cases, with clearer information, where the belief in feedback was present or absent, a positive or negative assessment on the use of the platform was given to evaluate justifications or specific aspects indicated beyond the details. The perception of usefulness of using this technology to evaluate occurs in teachers who believe that giving feedback to students is good and/or that learning happens through students' actions, rather than through the transmission of content.

\section{a. Acceptance of ICT integration in their practices}

As we examined in the initially cited research, there is a diversity of results in relation to the correspondence between beliefs and practices of ICT use. Although this study only relates perceptions, the results point to a confirmation of the point made by Ertmer et al., (2012) for the case of teachers in the school system (emerging in our case with higher education teachers)-that teachers who value the change of evaluation practices with technology integration correspondingly present specific beliefs about students, learning and/or evaluation.

The existence of two opposing tendencies among the teachers studied was clearly seen: those who adopt the use of the electronic portfolio in their pedagogical practice develop a clear sequence of beliefs and values conducive to learning from a perspective of professional competences, while those who show resistance to implementing this evaluation strategy respond to a concept of teaching centred on the teacher (see Graph 1).

The first assessment sequence using the platform involves teachers who believe in students' autonomy, recognise the great value of evaluation in feedback and demonstrate agreeing with learning practices centred on the student; they tend to positively value the electronic portfolio, 
even when they identify shortcomings in technological resources, training or in the process of project implementation, recognised as primary barriers (Ertmer, 1999; Ertmer et al., 2012).

... the advantage is that students have defined the deliverables from the beginning of the course in the system, they have everything there, the rubrics are defined from the beginning; therefore, it has to do with their effort and perseverance to be able to respond to the demands of the courses. So, that is an advantage, that students know from the beginning what they must deliver and through what guideline they will be evaluated.

It has certainly helped me, because as I was learning the technological tools, for example, I was forming groups that I was able to quickly evaluate... also, the fact of being able to assign different parameters that made up the rubric was a fairly quick and smooth procedure to evaluate.

... all this has contributed a lot to the system's flexibility and security, also, nothing is lost there and there are defined dates. It helps stay organised in teaching.

(Teacher interview 13)

Teachers who resist using Moodle for evaluation show a critical attitude towards the implementation of evidence-based evaluation strategies, hold beliefs about students' lack of autonomy to learn, identify problems of project implementation and access to digital resources as a difficulty and consider the experience of using the tool as negative or believe that it has disadvantages compared to traditional evaluation strategies.

Specifically, those who accepted the integration of the proposed technology showed beliefs about student-centred learning, the importance of autonomy in student work and/or identify with a concept of evaluation based on student performance. The primary barriers, which at one time were decisive technology acceptance, are below secondary ones related to teachers' beliefs.

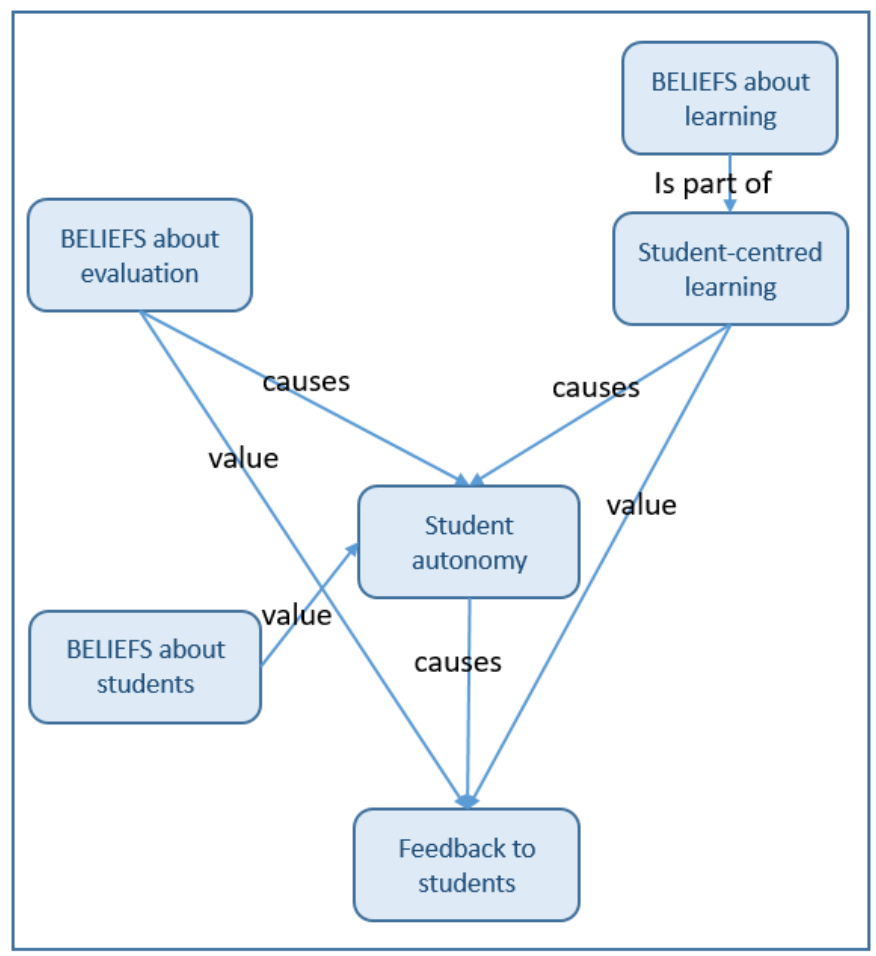

Figure 2. Assessment of autonomy and feedback Source: Created by the authors in AtlasTi 
Although the relationships presented in Figure 2 seem logical to us regarding the type of proposed technological adoption, it also alerts us to what (Cano, 2015a) noted regarding the difficulty of establishing competency-based assessment practices in higher education teachers. This is clearly visible in the data collected that point to student feedback as a practice that is derived from a series of prior beliefs regarding evaluation and learning, and thus being a necessary practice in a professional training based on competencies, it is not necessarily internalised.

Adherence to a training and evaluation approach that is based on student performance and not on the transmission or repetition of information is the background trigger in adopting this tool. The situation of faculty present in higher education institutions reflects the insecurity of assuming new ways of evaluating or a lack of references to rely on in the process of change (Margalef García, 2014).

\section{b. Behaviour of primary and secondary barriers}

An important aspect is that teachers, regardless of their area of knowledge and also, those more or less inclined to use ICT, value the use of the portfolio tool, and thus minimising the influence of training or security in ICT use as an important element that had weight in research during the late nineties (Ertmer, 1999; Pelgrum, 2001).

The sample group of teachers is satisfied with regard to access to technological resources and the means of connecting to the Internet, beyond some very specific difficulties on some campuses, which were remedied by changing rooms or spaces to conduct classes. We did not observe a relationship between this aspect and adherence to using the platform for assessment. Inclusively, those who call for more prepared rooms and/or greater Internet connection coverage tend to be teachers who value the integration of the platform.

We do not have a computer lab for our use, because other courses are favoured. I would like to have a computer per student, because not everyone has a laptop. So, we are working with one computer per group and we have to stop more.

(Teacher interview 17)

The barriers associated with beliefs in this case, focused largely on references to students, evaluation and learning. Thus, the teachers' statements in favour of or against student autonomy in the learning process and their beliefs about a performance-based or traditional-type evaluation process were key in the analysis.

As can be seen in Figure 3, which shows an overall view of the relationships found, the primary barriers related to the usability of the platform are one of the aspects that help with acceptance of its use. The main point is the ability to adapt this new technology to its former evaluation practices. 


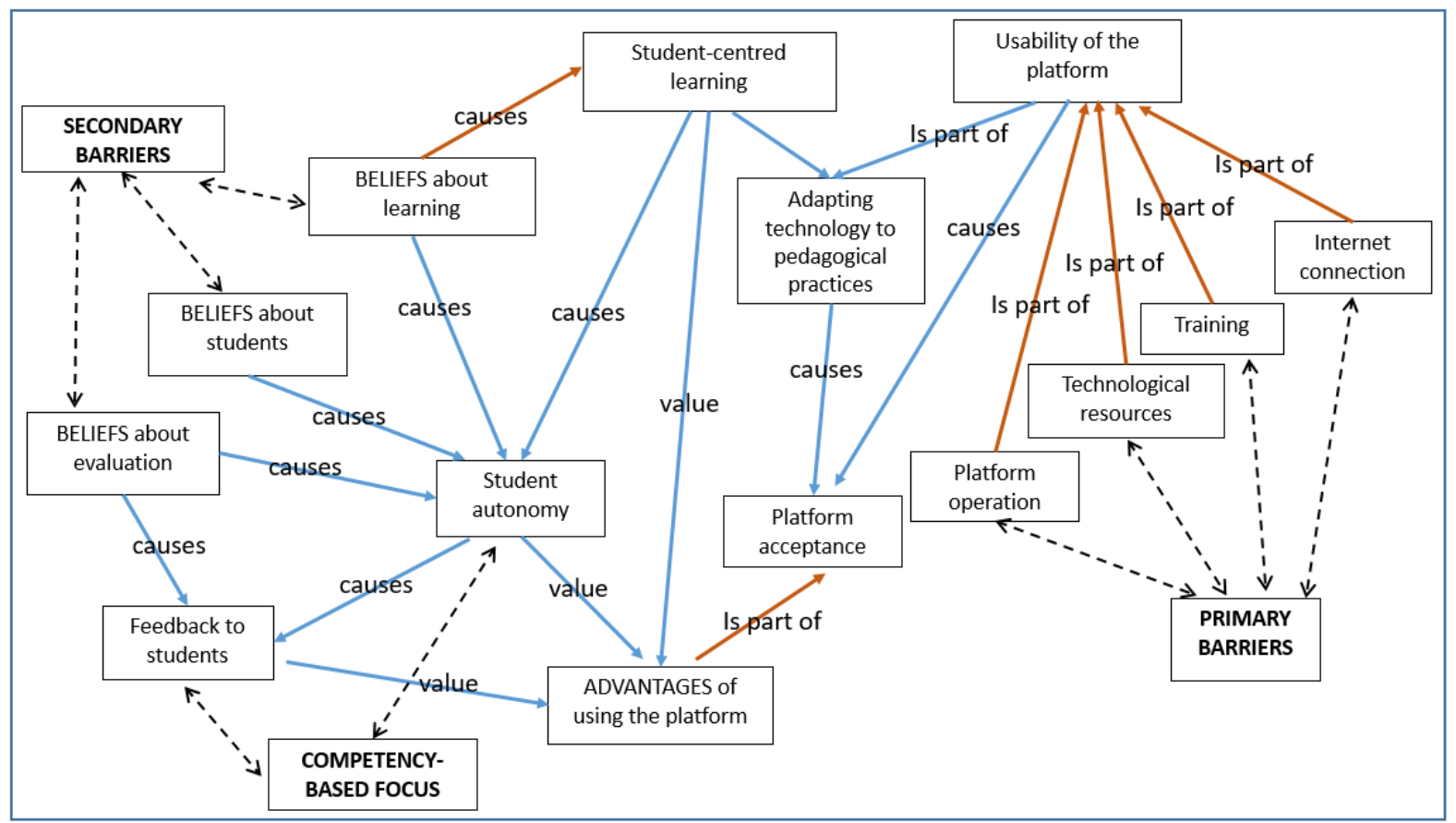

Figure 3. Relationships of primary and secondary barriers for acceptance of the technological tool in evaluation Source: Created by the authors in AtlasTi

On the other hand, this adaptation or acceptance of technology is more strongly linked to beliefs and the assessment of student autonomy, which is more similar to a closer look at competencybased training. The barriers are teachers' beliefs related to the way students must be assessed.

\section{c. The competency-based training approach as a barrier}

It is important to mention that although the studies refer more strongly of a correspondence between the integration of technology and an active or student-centred teaching approach, in the case of these teachers' beliefs, the evaluations regarding student characteristics and the value given to allow students' autonomous work, more than some other aspects, were indicated in the interviews and discussion groups.

Incorporating this tool is based on student autonomy in their learning, but this is new for students, (...) also, as first-year students, they do not have the intellectual maturity to work in a course with these characteristics. And with respect to evaluations, it is not balanced for academic excellence.

I have my objections (...) they lack a lot of information to be able to provide everything they have to provide. And, in addition, many evaluations are applied with rubrics that were not the most appropriate. (...) And as always, there were problems. The students had problems uploading homework to the platform. They always sent a copy to my email. As not everyone has a computer, we have another problem.

(Teacher 3, discussion group 1)

Teachers who find it difficult to integrate this technology show their differences about whether it is possible to give students autonomy in their comments, such as teacher 3 of discussion group 1. Or, 
they question whether these evaluation strategies focused on evidence of performance are of quality.

...the risk that students do not really show their true knowledge through the evaluation, that they really seem to know but really don't know much (...), if we evaluate them entirely with this type of evaluation element or evaluation tool (...) I believe that students' results would be catastrophic.

(Teacher interview 8)

The type of evaluation, through rubrics, makes it difficult to achieve objectivity, it is lost, because I do not have the overall view of the course as when evaluating traditionally...

(Teacher interview 9)

Thus, the difficulty or main barrier to make a change in practices lies in a more traditional perspective of evaluation. It is confirmed that the concept of evaluating through observation instruments such as rubrics generates an amount of uncertainty in some teachers, as Margalef García (2014) proves in a study on the competency assessment approach.

\section{Conclusions}

Social changes in the relationship with knowledge and technology have integrated in new demands for higher education training. The competency-based approach has been disseminated, and for its true implementation, it requires changes in the roles of teachers and students in the training process in general and evaluation in particular. This study investigated the difficulties affecting higher education teachers to make a change in evaluation practices with ICT integration using the Moodle platform. We managed to identify cases (Graph 1) that respond to pedagogical beliefs defined as the assessment of students' autonomous work and feedback in evaluation processes (Cano, 2015b; Panadero \& Jonsson, 2013), which corresponds with an acceptance of adopting ICT use to evaluate.

On the other hand, we found that, in this group, problems of access to technology were identified as primary barriers (Ertmer, 1999). They did not decisively influence the assessment of the integration of this new evaluative practice with the use of technology.

The characterisation of teachers' perceptions revealed some pedagogical beliefs that correspond with the acceptance of new technology used to evaluate. Due to the nature of the innovation experience studied, this study focused on evaluating performance, beliefs regarding competencybased training as well as evaluation strategies, and specifically the value of feedback, which were shown to be predominant at the moment to adhere or not to the proposal of using the platform. This allows us to observe how some practices with ICT can be fostered by previous pedagogical concepts (Arancibia et al., 2017), and at the same time, how these beliefs intertwine with the kind of practice promoted by the adopted technology (Tondeur, Van Braak, Ertmer, \& OttenbreitLeftwich, 2017).

The value of these characterisations again reveals the view that not only is it necessary to provide technological resources to teachers to promote the integration of ICT use, but that efforts should focus on training and access to experiences that help them assess new pedagogical perspectives and provide them with tools for change (Area Moreina et al., 2016; Area Moreira, 2006; Bosco et al., 2016; Ertmer et al., 2012; Romero \& Sancho, 2013). 
In addition, the cases found (five out of seventeen), as well as the comments related to the learning feedback, warn us about the point raised by Cano, (2015a) regarding the difficulty of establishing competency-based assessment practices in higher education teachers. Adherence to a training and evaluation approach that is based on student performance and not on the transmission or repetition of information is the background trigger to adopting this tool. This faculty situation is present in higher education institutions, which reflects the insecurity of assuming new ways of evaluating or a lack of references to rely on in the process of change (Margalef García, 2014).

Knowledge on pedagogical beliefs as well as the typologies of teachers according to these beliefs (Admiraal et al., 2017) should nurture teacher training policies and other socialisation initiatives of good practices, mentoring and tutoring, among others, that support changing practices in teaching and innovation with the use of ICT (Hargreaves, 2003; Reid, 2014; Salinas et al., 2017). Recognition among peers is also important for its adoption (Padilla et al., 2016), as well as care in the design of initiatives and the support necessary to develop expectations regarding change.

The identification of pedagogical beliefs in the face of processes of change and/or innovation with ICT use provides important information to conduct institutional policy and guarantee the conditions to sustain the change. As a result of this study, it is necessary to understand and contrast the perceptions of university students regarding pedagogical innovation, evaluation and the integration of ICT to identify where support is necessary and to solve the needs perceived by the students themselves.

\section{References}

Admiraal, W., Louws, M., Lockhorst, D., Paas, T., Buynsters, M., Cviko, A., ... Kester, L. (2017). Teachers in school-based technology innovations: A typology of their beliefs on teaching and technology. Computers and Education, 114, 57-68. https://doi.org/10.1016/j.compedu.2017.06.013

Álvarez-Gayou, J. (2003). Cómo hacer investigación cualitativa. Barcelona: Paidós Ibérica.

Arancibia, M. L., Halal, C., \& Romero, R. (2017). Valoración y barreras en la integración del e-portafolio en el proceso de práctica inicial por parte de docentes y estudiantes de Educación Superior. Píxel-Bit . Revista de Medios y Educación, 51, 151-163. https://doi.org/10.12795/pixelbit.2017.i51.10

Area Moreina, M., Hernández Rivero, V., \& Sosa Alonso, J. J. (2016). Modelos de integración didáctica de las TIC en el aula. Revista Científica de Educomunicación, 47(XXIV), 79-87. https://doi.org/10.3916/C472016-08

Area Moreira, M. (2006). Veinte años de políticas institucionales para incorporar las tecnologías de la información y comunicación al sistema escolar. En J. Sancho (Ed.), Tecnologías para transformar la educación (pp. 199-231). Madrid: Akal-Universidad Internaional de Andalucía.

Área Moreira, M., San Nicolás Santos, M. B., \& Fariña Vargas, E. (2010). Buenas prácticas de aulas virtuales en la docencia universitaria presencial. Revista Teoría de la Educación: Educación y Cultura en la Sociedad de la Información, 11(1), 7-31. Retrieved from http://revistatesi.usal.es/ revistas_trabajo/index.php/revistatesi/article/view/5787/5817

Bartolomé Piña, A. (2008). Entornos De Aprendizaje Mixto En Educación Superior. RIED. Revista Iberoamericana de Educación a Distancia, 11(1), 15-51. https://doi.org/10.5944/ried.1.11.955

Beneitone, P., Esquetini, C., Gonzáles, J., Marty, M., Siufi, G., \& Wagenaar, R. (2007). Proyecto Tuning América Latina-Informe Final: Reflexiones y perspectivas de la Educación Superior en América Latina. Bilbao: Universidad de Deusto. Retrieved from http://www.deustopublicaciones.es/deusto/pdfs/tuning/tuning05.pdf

Bosco, A., Sánchez-Valero, J. A., \& Sancho-Gil, J. M. (2016). Teaching practice and ICT in Catalonia: Consequences of educational policies. KEDI Journal of Educational Policy, 13(2), 201-220.

Boud, D., \& Molloy, E. (2015). El feedback en educación superior y profesional: Comprenderlo y hacerlo bien (Narcea Edi). Barcelona.

Camacho, L. J. (2014). Nuevos roles de los docentes en la educación superior: hacía un nuevo perfil y modelo de competencias con integración de las TIC. Xiencia y Sociedad, 39(4), 601-640. https://doi.org/10.22206/cys.2014.v39i4.pp601-640 
Cano, E. (2015a). Evaluación por competencias en educación superior. Madrid: La Muralla.

Cano, E. (2015b). Las rúbricas como instrumento de evaluación de competencias en Educación Superior: ¿Uso O Abuso? Profesorado. Revista de currículum y formación del profesorado, 19(2), 265-280. Retrieved from http://digibug.ugr.es/bitstream/handle/10481/37376/rev192COL2.pdf?sequence=1\&isAllowed=y

Cano, E., \& Ion, G. (2012). La formación del profesorado universitario para la implementación de la evaluación por competencias. Educación XX1,15(2), 249-270. https://doi.org/10.5944/educxx1.15.2.141

Cebrian de la Serna, M., Serrano Angulo, J., \& Ruiz Torres, M. (2014). Las e-rúbricas en la evaluación cooperativa del aprendizaje en la Universidad. Comunicar, 43(XXII), 153-161. https://doi.org/10.3916/C43-2014-15

Coll Salvador, C.; Rochera Villach, M. J.; Mayordomo Saiz, R. M.; Naranjo Llanos, M. (2008). La evaluación continuada como instrumento para el ajuste de la ayuda pedagógica y la enseñanza de competencias de autorregulación. César Coll, María José Rochera, Rosa María Mayordomo, Milagros Naranjo 1. Retrieved from http://www.ub.edu/ice/sites/default/files/docs/qdu/8cuaderno.pdf

Dominguez Díaz, Y. (2016). La utilización de las Tecnologías de la Información y las Comunicaciones (TIC) en el apren- dizaje universitario. Universidad y Sociedad, 8(4), 158-163. Retrieved from http://scielo.sld.cu/scielo.php?script=sci_arttext\&pid=S2218-36202016000400021

Ertmer, P. A. (1999). Addressing first- and second-order barriers to change: Strategies for technology integration. Educational Technology Research and Development, 47(4), 47-61. https://doi.org/10.1007/BF02299597

Ertmer, P. A., Ottenbreit-Leftwich, A. T., Sadik, O., Sendurur, E., \& Sendurur, P. (2012). Teacher beliefs and technology integration practices: A critical relationship. Computers and Education, 59(2), 423-435. https://doi.org/10.1016/j.compedu.2012.02.001

Espinosa, M. T. (2014). Necesidades formativas docente universitario . Training needs of university Introducción. REDU Revista de docencia universitaria, 12(4), 161-177. Retrieved from https://polipapers.upv.es/index.php/REDU/article/view/5619

Fainholc, B., Nervi, H., Romero, R., \& Halal, C. (2015). La formación del profesorado y el uso pedagógico de las TIC. Revista de educación a distancia, (38), 1-14. Retrieved from https://revistas.um.es/red/article/view/234081

Flick, U. (2007). Introducción a la investigación cualitativa. Madrid: Morata.

Flick, U. (2015). Qualitative Inquiry-2.0 at 20? Developments, Trends, and Challenges for the Politics of Research. Qualitative Inquiry, 21(7), 599-608. https://doi.org/10.1177/1077800415583296

Forés, A., Sánchez, J.-A., \& Sancho-Gil, J. M. (2014). Salir de la zona de confort. Dilemas y desafíos en el EEES. Tendencias Pedagógicas, 23, 205-214. Retrieved from https://repositorio.uam.es/handle/10486/660088

García-Varcárcel, A. (2011). Integración de las Tic en la Docencia Universitaria. La Coruña: Netbiblo.

Gil Flores, J., \& Padilla Carmona, M. T. (2013). La participación del alumnado universitario en la evaluación del aprendizaje. Educación $X X 1,12(0)$. Retrieved from http://espacio.uned.es/fez/eserv/bibliuned:EducacionXXI-2009-12-3020/Documento.pdf

Hargreaves, A. (2003). Educar en la sociedad del conocimiento. Barcelona: Octaedro.

Hargreaves, A., \& Fink, D. (2004). The seven principles of sustainable leadership. Educational Leadership, $61(7), 8-13$

Kim, C. M., Kim, M. K., Lee, C., Spector, J. M., \& DeMeester, K. (2013). Teacher beliefs and technology integration. Teaching and Teacher Education, 29, 76-85. https://doi.org/10.1016/j.tate.2012.08.005

Le Boterf, G. (2011). Repenser la Competence. Paris: Eyrolles.

Liu, S. H. (2011). Factors related to pedagogical beliefs of teachers and technology integration. Computers \& Education, 56(4), 1012-1022. https://doi.org/10.1016/j.compedu.2010.12.001

Manso, M., Pérez, P., Libedinsky, M., Light, D., \& Garzón, M. (2011). Las TIC en las aulas. Experiencias latinoamericanas. Buenos Aires: Paidós Ibérica.

Margalef García, L. (2014). Evaluación formativa de los aprendizajes en el contexto universitario: Resistencias y paradojas del profesorado. Educacion XX1, 17(2), 35-55. https://doi.org/10.5944/educxx1.17.2.11478

Martín García, A. V., García del Dujo, Á., \& Muñoz Rodríguez, J. M. (2014). Factores determinantes de adopción de blended learning en educación superior. Adapta ción del modelo UTAUT. Educacion XX1, 17(2), 217240. https://doi.org/10.5944/educxx1.17.2.11489

Mateo, J., \& Vlachopoulos, D. (2013). Evaluación en la universidad en el contexto de un nuevo para- digma 
para la educación superior. Educación XXI, 16(2), 183-208. https://doi.org/10.5944/educxx1.2.16.10338

Medina Moya, J. L., Jarauta Borrasca, B., \& Urquiza Sánchez, C. (2005). Evaluación del impacto de la formación del profesorado universitario novel: un estudio cualitativo. Revista de Investigación Educativa, 23(1), 205-238. Retrieved from http://revistas.um.es/rie/article/view/98511

OECD. (2005). E-learning in Tertiary Education. Policy brief. https://doi.org/10.1177/0022146512469014

Pablos Pons, J. de, Colás Bravo, M. P., \& Villaciervos Moreno, P. (2010). Politicas educativas, buenas prácticas y TIC en la Comunidad Autónoma Andaluza. Teoría de la Educación en la Sociedad de la Información, 11(1), 180-202. Retrieved from http://revistas.usal.es/index.php/eks/article/viewFile/5842/5868

Padilla, S., Moreno, C. I., \& Hernández, R. (2016). Barreras para la integración de buenas prácticas con TIC. Estudio de caso. Innoeduca. International Journal of Technology and Educational Innovation, 1(2), 80. Retrieved from http://www.revistas.uma.es/index.php/innoeduca/article/view/1044/1006

Panadero, E., \& Jonsson, A. (2013). The use of scoring rubrics for formative assessment purposes revisited: A review. Educational Research Review, 9(October 2018), 129-144. https://doi.org/10.1016/j.edurev.2013.01.002

Pelgrum, W. J. (2001). Obstacles to the integration of ICT in education: Results from a worldwide educational assessment. Computers and Education, 37(2), 163-178. https://doi.org/10.1016/S0360-1315(01)000458

Pérez-Berenguer, D., \& García-Molina, J. (2016). Un enfoque para la creación de contenido online interactivo. Revista de Educación a Distancia (RED), (51). https://doi.org/10.6018/red/51/3

Perrenaud, P. (2004). Diez nuevas competencias para enseñar. Barcelona: Graó.

Reid, P. (2014). Categories for barriers to adoption of instructional technologies. Education and Information Technologies, 19(2), 383-407. https://doi.org/10.1007/s10639-012-9222-z

Reyes González, D., \& Martín García, A. (2016). Creencias de docentes en formación que afectan el uso de recursos tecnológicos. Ciencia, Docencia y Tecnología, 27(53), 293-314. Retrieved from http://pcient.uner.edu.ar/index.php/cdyt/article/view/205

Romero, R., \& Halal, C. (2013). Rediseño de un programa de formación de postgrado bajo un modelo basado en competencias. Desarrollo del perfil de egreso. En S. Tobón (Ed.), Aplicación de las competencias en la docencia, la sociedad y las organizaciones (pp. 443-464). Miami: CreateSpace Independent Publishing Platform.

Romero, R., \& Sancho, J. M. (2013). La política en informática educativa en Chile. Visiones y creencias sobre su implementación. Universidad de Barcelona. Retrieved from https://www.tdx.cat/bitstream/handle/10803/123494/RERA_TESIS.pdf?sequence=1\&isAllowed=y

Saldaña, J. (2013). The Coding Manualfor Qualitative Researchers. London: SAGE Publications.

Salinas, Á., Nussbaum, M., Herrera, O., Solarte, M., \& Aldunate, R. (2017). Factors affecting the adoption of information and communication technologies in teaching. Education and Information Technologies, 22(5), 2175-2196. https://doi.org/10.1007/s10639-016-9540-7

Sancho-Gil, J. M., Alonso Cano, C., \& Sánchez-Valero, J. A. (2018). Miradas retro-prospectivas sobre las Tecnologías Educativas. Educatio Siglo XXI, 36(2), 209-228. https://doi.org/10.6018/j/333051

Schreier, M. (2014). Varianten qualitativer Inhaltsanalyse: Ein Wegweiser im Dickicht der Begrifflichkeiten. Forum Qualitative Sozialforschung / Forum: Qualitative Social Research, 15(1). Retrieved from https://goo.gl/BPQZ2Z

Stake, R. (2007). Investigación con estudio de casos ( $4^{\mathrm{a}}$ ed.). Madrid: Morata.

Staller, K. M. (2015). Qualitative analysis: The art of building bridging relationships. Qualitative Social Work, 14(2), 145-153. https://doi.org/10.1177/1473325015571210

Suárez, M. (2005). El Grupo de Discusión. Una herramienta para la Investigación Cualitativa. Barcelona: Laertes.

Tapasco, O. A., \& Giraldo, J. A. (2017). Estudio comparativo sobre percepción y uso de las tic entre profesores de universidades públicas y privadas. Formacion Universitaria, 10(2), 3-12. https://doi.org/10.4067/S0718-50062017000200002

Tardif, J. (2008). Desarrollo de un programa por competencias : De la intención a su implementación. Profesorado. Revista de currículum y formación del profesorado, 12(3), 1-16. Retrieved from https://recyt.fecyt.es/index.php/profesorado/article/view/41516

Tejada Fernández, J. (2012). La alternancia de contextos para la adquisición de competencias profesionales en escenarios complementarios de educación superior: Marco y estrategia. Educacion XX1, 15(2), 17-40. https://doi.org/10.5944/educxx1.15.2.125 
Tejada Fernández, J., \& Ruiz Bueno, C. (2016). Evaluación de competencias profesionales en educación superior: Retos e implicaciones. Educacion XX1, 19(1), 17-38. https://doi.org/10.5944/educXX1.12175

Tondeur, J., Hermans, R., van Braak, J., \& Valcke, M. (2008). Exploring the link between teachers' educational belief profiles and different types of computer use in the classroom. Computers in Human Behavior, 24(6), 2541-2553. https://doi.org/10.1016/j.chb.2008.02.020

Tondeur, J., Van Braak, J., Ertmer, P., \& Ottenbreit-Leftwich, A. (2017). Understanding the relationship between teachers' pedagogical beliefs and technology use in education: a systematic review of qualitative evidence. Educational Technology Research and Development, 65(3), 555-575. https://doi.org/10.1007/s11423-016-9492-z.

Valle, J., \& Manso, J. (2013). Competencias clave como tendencia de la política educative supranacional de la Unión Europea. Revista de Educacion, (EXTRA 2013), 12-33. https://doi.org/10.4438/1988-592X-RE2013-EXT-255

Zabalza Beraza, M. A. (2009). Ser profesor universitario hoy. La cuestión Universitaria, 5, 69-81. Retrieved from http://polired.upm.es/index.php/lacuestionuniversitaria/article/view/3338/3403 